\title{
PERBANDINGAN DECISION TREE J48, REPTREE, DAN RANDOM TREE DALAM MENENTUKAN PREDIKSI PRODUKSI MINYAK KELAPA SAWIT MENGGUNAKAN METODE FUZZY TSUKAMOTO
}

\author{
Tundo*1, Shofwatul 'Uyun ${ }^{2}$ \\ 1,2UIN Sunan Kalijaga Yogyakarta \\ Email: 19asna8mujahid@gmail.com, 22shofwatul.uyun@uin-suka.ac.id \\ *Penulis Korespondensi
}

(Naskah masuk: 17 Januari 2019, diterima untuk diterbitkan: 08 Juni 2021)

\begin{abstract}
Abstrak
Penelitian ini menerangkan analisis decision tree J48, REPTree dan Random Tree dengan menggunakan metode fuzzy Tsukamoto dalam penentuan jumlah produksi minyak kelapa sawit di perusahaan PT Tapiana Nadenggan dengan tujuan untuk mengetahui decision tree mana yang hasilnya mendekati dari data sesungguhnya. Digunakannya decision tree J48, REPTree, dan Random Tree yaitu untuk mempercepat dalam pembuatan rule yang digunakan tanpa harus berkonsultasi dengan para pakar dalam menentukan rule yang digunakan. Berdasarkan data yang digunakan akurasi pembentukan rule dari decision tree $\mathrm{J} 48$ adalah 95,2381\%, REPTree adalah 90,4762\%, dan Random Tree adalah 95,2381\%. Hasil dari penelitian yang telah dihitung bahwa metode fuzzy Tsukamoto dengan menggunakan REPTree mempunyai error Average Forecasting Error Rate (AFER) yang lebih kecil sebesar 23,17 \% dibandingkan dengan menggunakan J48 sebesar 24,96 \% dan Random Tree sebesar 36,51 $\%$ pada prediksi jumlah produksi minyak kelapa sawit. Oleh sebab itu ditemukan sebuah gagasan bahwa akurasi pohon keputusan yang terbentuk menggunakan tools WEKA tidak menjamin akurasi yang terbesar adalah yang terbaik, buktinya dari kasus ini REPTree memiliki akurasi rule paling kecil, akan tetapi hasil prediksi memiliki tingkat error paling kecil, dibandingkan dengan J48 dan Random Tree.
\end{abstract}

Kata kunci: Logika Fuzzy, Decision Tree, J48, REPTree, Random Tree, Fuzzy Tsukamoto.

\section{COMPARISON OF DECISION TREE J48, REPTREE, AND TREE RANDOM IN DETERMINING THE PREDICTION OF PALM OIL PRODUCTION USING THE FUZZY TSUKAMOTO METHOD}

\begin{abstract}
This study explains the J48, REPTree and Tree Random tree decision analysis using Tsukamoto's fuzzy method in determining the amount of palm oil production in PT Tapiana Nadenggan's company with the aim of finding out which decision tree results are close to the actual data. The decision tree J48, REPTree, and Random Tree is used to accelerate the making of rules that are used without having to consult with experts in determining the rules used. Based on the data used the accuracy of the rule formation of the J48 decision tree is $95.2381 \%$, REPTree is $90.4762 \%$, and the Random Tree is $95.2381 \%$. The results of the study have calculated that the Tsukamoto fuzzy method using REPTree has a smaller Average Forecasting Error Rate (AFER) rate of 23.17\% compared to using $J 48$ of $24.96 \%$ and Tree Random of $36.51 \%$ in the prediction of the amount of palm oil production. Therefore an idea was found that the accuracy of decision trees formed using WEKA tools does not guarantee the greatest accuracy is the best, the proof of this case REPTree has the smallest rule accuracy, but the predicted results have the smallest error rate, compared to J48 and Tree Random.
\end{abstract}

Keywords: Fuzzy Logic, Decision Tree, J48, REPTree, Tree Random, Fuzzy Tsukamoto.

\section{PENDAHULUAN}

Produksi adalah suatu kegiatan yang dikerjakan untuk menambah nilai guna suatu benda sehingga lebih bermanfaat untuk memenuhi kebutuhan orang banyak (Kusumadewi, 2010). Dalam perusahaan besar proses produksi adalah hal yang selalu diperhatikan karena kunci utama pengusaha untuk menentukan kualitas produk yang dihasilkan adalah dari produksi yang dihasilkan (Solikin, 2013). Setelah mengetahui kualitas produksi dari produk yang dihasilkan tahap selanjutnya yaitu dapat memperkirakan produksi yang dihasilkan berdasarkan faktor-faktor yang mempengaruhi proses produksi. Dalam penelitian ini, membahas tentang 
produksi minyak kelapa sawit yang dipengaruhi oleh faktor banyaknya minyak kelapa sawit dalam satuan kilogram, permintaan konsumen dalam satuan liter, dan persediaan minyak kelapa sawit yang tersedia dalam satuan liter. Manfaat dari prediksi produksi pada suatu perusahaan antara lain dapat memperkirakan jumlah produksi yang terbentuk berdasarkan faktor yang dipengaruhi, mempermudah perencanaan hasil keuntungan yang akan diperoleh, serta dalam jangka kedepan akan sangat berguna ketika proses produksi mengalami peningkatan yang signifikan karena adanya sistem yang dapat membantu menangani prediksi produksi minyak kelapa sawit di PT Tapian Nadenggan sebelum proses produksi tersebut menjadi bahan matang yang siap untuk dikonsumsi. Banyak metode yang dapat menangani proses prediksi dalam menentukan jumlah produksi minyak kelapa sawit diantaranya adalah metode fuzzy. Metode fuzzy yang peneliti gunakan adalah fuzzy Tsukamoto dengan menggunakan kombinasi decision tree J48, REPTree dan Random Tree. Manfaat dari decision tree J48, REPTree, dan Random Tree adalah untuk membuat rule secara otomatis dari data yang ada, tanpa harus bersusah paya konsultasi dengan ahli pakar untuk membuat rule yang sesuai dengan faktor yang mempengaruhi proses produksi minyak kelapa sawit.

Berikut beberapa penelitian yang serupa yang peneliti ambil sebagai bahan dalam pembuatan penelitian ini. Pertama menurut (Selywita and Hamdani, 2013) melakukan penelitian mengenai supplier obat dengan menggunakan metode fuzzy Tsukamoto dengan rule yang digunakan adalah rule monoton, dengan kriteria yang ada yaitu, harga, pengalaman, dan waktu. Kedua menurut (Tseng, Konada and Kwon, 2016) melakukan penelitian memprediksi kekasaran permukaan dalam operasi pemesinan menggunakan teori himpunan fuzzy Tsukamoto dengan akurasi yang dihasilkan sebesar 95\%. Ketiga menurut (Juliansyah, 2015) melakukan penelitian berkaitan tentang penerapan metode fuzzy Tsukamoto dalam memprediksi minyak kelapa sawit dengan menggunakan kriteria permintaan dan persediaan dengan akurasi sebesar $82 \%$. Keempat menurut (Harsiti, Munandar and Sigit, 2013) mekakukan penelitian mengenai implementasi klasikfikasi fuzzy-C4.5 sebagai pendukung dalam pemilihan spesialisasi siswa dengan akurasi yang didapat sebesar $86.51 \%$. Kelima menurut (Hidayati et al., 2013) melakukan penelitian mengenai optimalisasi mitra bisnis kelayakan untuk revitalisasi kelapa sawit dengan menggunakan fuzzy Analytic Hierarchy Process (AHP) dengan akurasi sebesar 55\%. Keenam menurut (Tundo and Sela, 2018) melakukan penelitian prediksi produksi kain tenun dengan menggunakan metode decision tree sebagai base rule yang akan dibentuk dengan menggunakan metode fuzzy Tsukamoto dan Sugeno dimana hasil yang didapat adalah metode dengan menggunakan fuzzy Tsukamoto dengan akurasi $83.3333 \%$. dan yang terakhir menurut (Sukandy, Basuki and Puspasari, 2014) melakukan penelitian tentang prediksi produksi minyak kelapa sawit dengan kriteria persediaan dan jumlah permintaan diperoleh akurasi sebesar $86.67 \%$. Berdasarkan hal-hal yang telah dijelaskan di atas, pemodelan penelitian yang dilakukan adalah mengumpulkan semua data yang ada, kemudian di bantu dengan tools WEKA untuk memperoleh rule yang terbentuk dengan menggunakan decision tree J48, REPTree dan Random Tree, kemudian dihitung dengan menggunakan metode fuzzy Tsukamoto.

\section{METODE PENELITIAN}

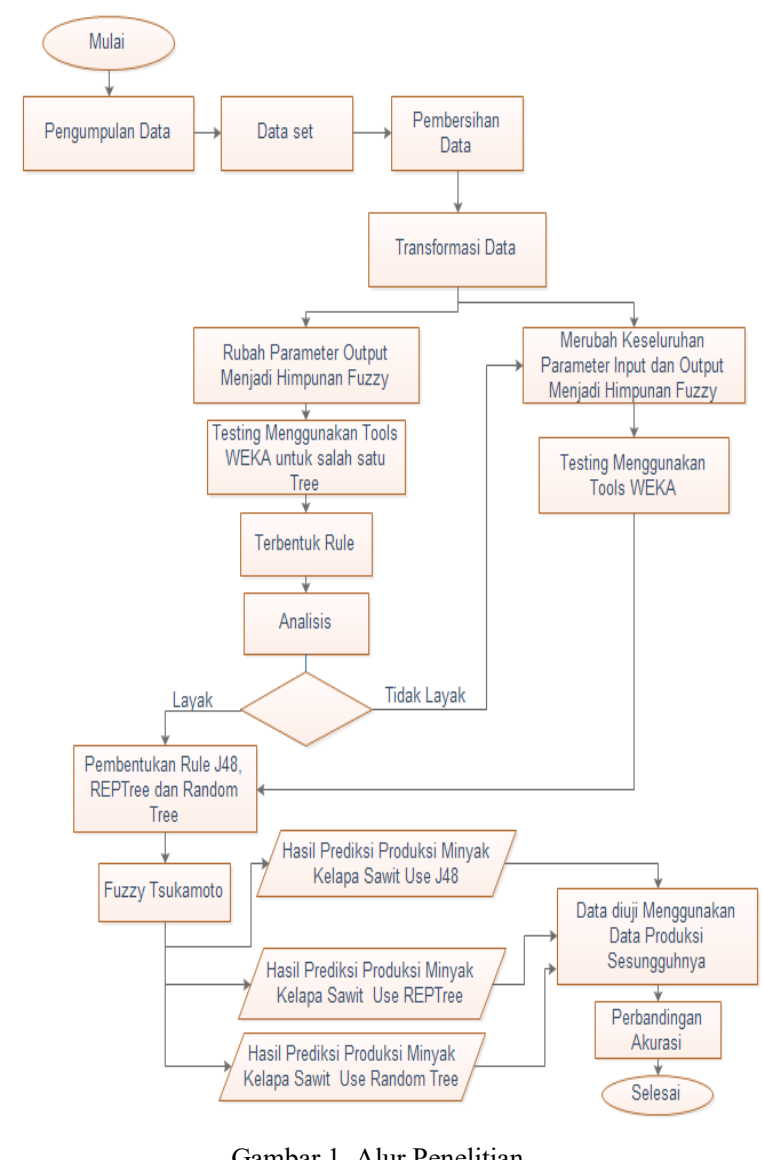

Gambar 1. Alur Penelitian

1) Pengumpulan Data

Pengumpulan Data dilakukan setiap bulan sekali, dimulai dari bulan Januari tahun 2014 dengan meminta data dari salah satu karyawan dibagian gudang yang mengurusi tentang pencatatan logistik di PT Tapian Nadenggan sampai dengan bulan Maret tahun 2019.

\section{2) Dataset}

Dataset adalah data yang sudah terkumpul yang akan digunakan dalam menentukan pembentukan pohon keputusan dengan menggunakan tools WEKA untuk decision tree J48, REPTree, dan Random Tree.

\section{3) Pembersihan Data}

Pembersihan Data adalah proses melakukan seleksi data yang diperlukan, yakni ambil data yang 
diperlukan saja untuk membentuk pohon keputusan dengan menggunakan tools WEKA untuk decision tree J48, REPTree, dan Random Tree. Data yang diperlukan untuk membentuk pohon keputusan tersebut, yaitu kelapa sawit, permintaan, persediaan, dan produksi.

4) Transformasi Data

Tranformasi Data adalah proses melakukan perubahan data dari data numerik menjadi himpunan fuzzy (Mujahid and Sela, 2019). Terdapat dua macam dalam membuat transformasi dalam kasus ini, yakni sebagai berikut:

a. Mengubah Parameter Output Menjadi Himpunan Fuzzy

Perubahan parameter kriteria output produksi yang awalnya bernilai numerik dirubah kedalam bentuk nilai himpunan fuzzy (Tundo, Akbar and Sela, 2020). Himpunan fuzzy untuk kriteria produksi diklasifikasikan menjadi sedikit, sedang, dan banyak. Langkah berikutnya tampak seperti gambar di bawah ini:

1. Testing Menggunakan Tools WEKA untuk Salah satu Tree

Untuk mengetahui nilai batasan dan rule yang terbentuk beserta akurasi yang dihasilkan.

\section{Terbentuk Rule}

Bentuk rule yang terbaik adalah akurasi yang mendekati $100 \%$, jika masih jauh dari $100 \%$ maka perlu dirubah kembali data pada Tabel 3. Perubahan Kriteria Output Produksi.

3. Analisis

Rule yang terbentuk dan telah mendekati $100 \%$, dianalisis untuk mengetahui rule tersebut layak digunakan atau tidak. Dikatakan layak maka dalam satu rule tidak ada kriteria yang terulang kembali. Jika ada maka perlu melakukan transformasi kembali, yakni merubah semua kriteria menjadi himpunan fuzzy.

b. Mengubah Semua Parameter Input dan Output Menjadi Himpunan Fuzzy

Perubahan semua parameter kriteria input dan output menjadi himpunan fuzzy dengan maksud untuk menghindari rule yang terbentuk terulang kembali.

5) Pembentukan Rule J48, REPTree, dan Random Tree

Pembentukan rule dengan menggunakan tools WEKA dengan decision tree yang digunakan adalah J48, REPTree, dan Random Tree.

6) Fuzzy Tsukamoto

Semua rule yang terbentuk dari J48, REPTree, dan Random Tree, kemudian untuk menentukan hasil prediksi yaitu menggunakan metode Fuzzy Tsukamoto.

7) Uji Data Menggunakan Data Produksi Sesungguhnya

Hasil prediksi menggunakan rule J48, REPTree, dan Random Tree dengan metode Fuzzy Tsukamoto, kemudian dibandingkan dengan data produksi sesungguhnya.

8) Perbandingan Akurasi

Perbandingan akurasi menggunakan metode error Average Forecasting Error Rate (AFER) untuk mengetahui rule J48, REPTree, dan Random Tree mana yang lebih mendekati dari data produksi sesungguhnya.

\section{PEMBAHASAN DAN HASIL}

\subsection{Analisis Pembentukan Pohon Keputusan Dan Fuzzy Tsukamoto}

Siapkan dataset yang sudah diperoleh di PT Tapian Nadenggan untuk digunakan dalam membuat pohon keputusan J48, REPTree, dan Random Tree, dimana dataset tersebut tampak pada Tabel 1 . Dataset berikut:

\begin{tabular}{cccccc}
\multicolumn{6}{c}{ Tabel 1. Dataset } \\
\hline Bulan Tahun & $\begin{array}{c}\text { Kelapa } \\
\text { Sawit } \\
(\mathrm{Kg})\end{array}$ & $\begin{array}{c}\text { Perminta } \\
\text { an(Liter) }\end{array}$ & $\begin{array}{c}\text { Persediaa } \\
\text { n (Liter) }\end{array}$ & $\begin{array}{c}\text { Produksi } \\
\text { (Liter) }\end{array}$ \\
\hline 01 & 2014 & 20.875 .000 & 4.730 .000 & 3.960 .000 & 10.020 .000 \\
02 & 2014 & 26.300 .000 & 14.987 .000 & 4.220 .000 & 19.300 .000 \\
03 & 2014 & 26.250 .000 & 14.980 .000 & 4.500 .000 & 19.150 .000 \\
04 & 2014 & 38.700 .000 & 3.784 .000 & 1.900 .000 & 10.100 .000 \\
05 & 2014 & 24.400 .000 & 7.568 .000 & 4.000 .000 & 13.568 .000 \\
06 & 2014 & 26.000 .000 & 12.600 .000 & 1.730 .000 & 17.000 .000 \\
07 & 2014 & 34.857 .100 & 10.811 .400 & 3.959 .140 & 18.954 .280 \\
08 & 2014 & 23.384 .600 & 5.821 .540 & 3.988 .460 & 10.500 .000 \\
09 & 2014 & 36.200 .000 & 14.980 .000 & 1.100 .000 & 18.920 .000 \\
10 & 2014 & 36.415 .100 & 13.962 .200 & 4.886 .790 & 17.252 .830 \\
11 & 2014 & 37.480 .000 & 15.136 .000 & 1.600 .000 & 19.636 .000 \\
12 & 2014 & 36.415 .100 & 7.139 .620 & 2.886 .790 & 15.052 .830 \\
01 & 2015 & 34.500 .000 & 7.153 .330 & 1.995 .000 & 12.220 .000 \\
02 & 2015 & 43.500 .000 & 10.977 .500 & 833.333 & 19.000 .000 \\
03 & 2015 & 25.375 .000 & 11.035 .000 & 2.916 .670 & 18.138 .460 \\
04 & 2015 & 41.428 .600 & 18.920 .000 & 5.000 .000 & 19.800 .000 \\
05 & 2015 & 36.730 .800 & 12.769 .200 & 4.923 .080 & 18.700 .000 \\
06 & 2015 & 27.250 .000 & 3.153 .333 & 1.428 .570 & 6.000 .000 \\
07 & 2015 & 20.116 .300 & 4.400 .000 & 1.962 .790 & 13.237 .210 \\
08 & 2015 & 35.593 .800 & 5.912 .500 & 3.960 .000 & 12.000 .000 \\
$\ldots$. & $\ldots$. & $\ldots$. & $\ldots$. & $\ldots$. & $\ldots$. \\
$\ldots$. & $\ldots$. & $\ldots$. & $\ldots$. & $\ldots$. & $\ldots$. \\
$\ldots$. & $\ldots$. & $\ldots$. & $\ldots$. & $\ldots$. & $\ldots$. \\
02 & 2019 & 40.616 .100 & 14.996 .800 & 4.969 .670 & 19.597 .200 \\
\hline & & & & & \\
\hline
\end{tabular}

Tahap selanjutnya, pada Tabel 1. Dataset lakukan pembersihan data, yakni ambil data yang diperlukan saja untuk membentuk pohon keputusan J48, REPTree, dan Random Tree dengan menggunakan tools WEKA. Data yang diperlukan pembentukan pohon keputusan adalah kelapa sawit, permintaan, persediaan, dan produksi. Langkah berikutnya adalah melakukan transformasi data dengan 2 cara seperti berikut:

a. Rubah Parameter Output Menjadi Himpunan Fuzzy 
Perubahan kriteria output produksi yang awalnya bernilai numerik dirubah kedalam bentuk nilai himpunan fuzzy. Himpunan fuzzy untuk kriteria produksi diklasifikasikan menjadi sedikit, sedang, dan banyak. Tujuan diklasifikasikan menjadi himpunan fuzzy untuk mendapatkan klasifikasi dari masing masing kriteria yakni berupa nilai batasan. Nilai batasan tersebut yang akan menentukan nilai tersebut tergolong dalam himpunan fuzzy sedikit, sedang, atau banyak. Cara mudah untuk melakukan klasifikasi tersebut dengan mengambil nilai minimal, titik tengah, dan nilai maksimal dari kriteria produksi, lalu dari nilai minimal sampai mendekati titik tengah asumsikan klasifikasi sedikit, dari mendekati titik tengah sampai mendekati nilai maksimal asumsikan klasifikasi sedang, kemudian dari mendekati nilai maksimal sampai ke nilai maksimal asumsikan klasifikasi banyak, sehingga nampak seperti pada Tabel 3 . Perubahan Kriteria Output Produksi, setelah itu diuji menggunakan tools WEKA, maka akan muncul akurasi klasifikasi, ketika akurasi dinilai masih sangat jauh dari yang diharapkan, maka acak kembali nilai produksi tersebut, sehingga akurasi yang didapat mendekati $100 \%$, yang artinya data kebenarannya lebih besar daripada data kesalahannya.Berikut dapat dilihat pada Tabel 2. Perubahan Kriteria Output Produksi di bawah ini:

\begin{tabular}{|c|c|c|c|}
\hline $\begin{array}{c}\text { Kelapa } \\
\text { Sawit }(\mathrm{Kg})\end{array}$ & $\begin{array}{l}\text { Permintaan } \\
\text { (Liter) }\end{array}$ & $\begin{array}{l}\text { Persediaan } \\
\text { (Liter) }\end{array}$ & $\begin{array}{c}\text { Produksi } \\
\text { (Liter) }\end{array}$ \\
\hline 20.875 .000 & 4.730 .000 & 3.960 .000 & Sedikit \\
\hline 26.300 .000 & 14.987 .000 & 4.220 .000 & Banyak \\
\hline 26.250 .000 & 14.980 .000 & 4.500 .000 & Banyak \\
\hline 38.700 .000 & 3.784 .000 & 1.900 .000 & Sedikit \\
\hline 24.400 .000 & 7.568 .000 & 4.000 .000 & Sedang \\
\hline 26.000 .000 & 12.600 .000 & 1.730 .000 & Banyak \\
\hline 34.857 .100 & 10.811 .400 & 3.959 .140 & Banyak \\
\hline 23.384 .600 & 5.821 .540 & 3.988 .460 & Sedikit \\
\hline 36.200 .000 & 14.980 .000 & 1.100 .000 & Banyak \\
\hline 36.415 .100 & 13.962 .200 & 4.886 .790 & Banyak \\
\hline 37.480 .000 & 15.136 .000 & 1.600 .000 & Banyak \\
\hline 36.415 .100 & 7.139 .620 & 2.886 .790 & Sedang \\
\hline 34.500 .000 & 7.153 .330 & 1.995 .000 & Sedikit \\
\hline 43.500 .000 & 10.977 .500 & 833.333 & Banyak \\
\hline 25.375 .000 & 11.035 .000 & 2.916 .670 & Banyak \\
\hline 41.428 .600 & 18.920 .000 & 5.000 .000 & Banyak \\
\hline 36.730 .800 & 12.769 .200 & 4.923 .080 & Banyak \\
\hline 27.250 .000 & 3.153 .333 & 1.428 .570 & Sedikit \\
\hline 20.116 .300 & 4.400 .000 & 1.962 .790 & Sedang \\
\hline 35.593 .800 & 5.912 .500 & 3.960 .000 & Sedikit \\
\hline & …….......... & …….......... & ……......... \\
\hline …............... & $\ldots \ldots \ldots$ & ................. & ................. \\
\hline 27.187 .500 & 14.985 .000 & 1.825 .000 & Banyak \\
\hline
\end{tabular}

Setelah itu, lakukan testing pembentukan pohon keputusan menggunakan tools WEKA untuk mengetahui pohon keputusan yang terbentuk layak atau tidak, ketika layak maka dalam satu aturan pohon keputusan tersebut tidak ada kriteria yang terulang kembali atau redudansi data, maka testing tersebut dapat digunakan, tetapi jika tidak layak maka perlu dibentuk ulang kembali dengan menemukan setiap batasan nilai himpunan fuzzy dari setiap kriteria. Batasan nilai himpunan fuzzy dapat ditemukan dari testing pembentukan pohon keputusan tersebut, lalu ubah semua nilai kriteria menjadi himpunan fuzzy sesuai dengan nilai batasan yang ada. Berikut hasil testing pohon keputusan yang dihasilkan menggunakan J48.

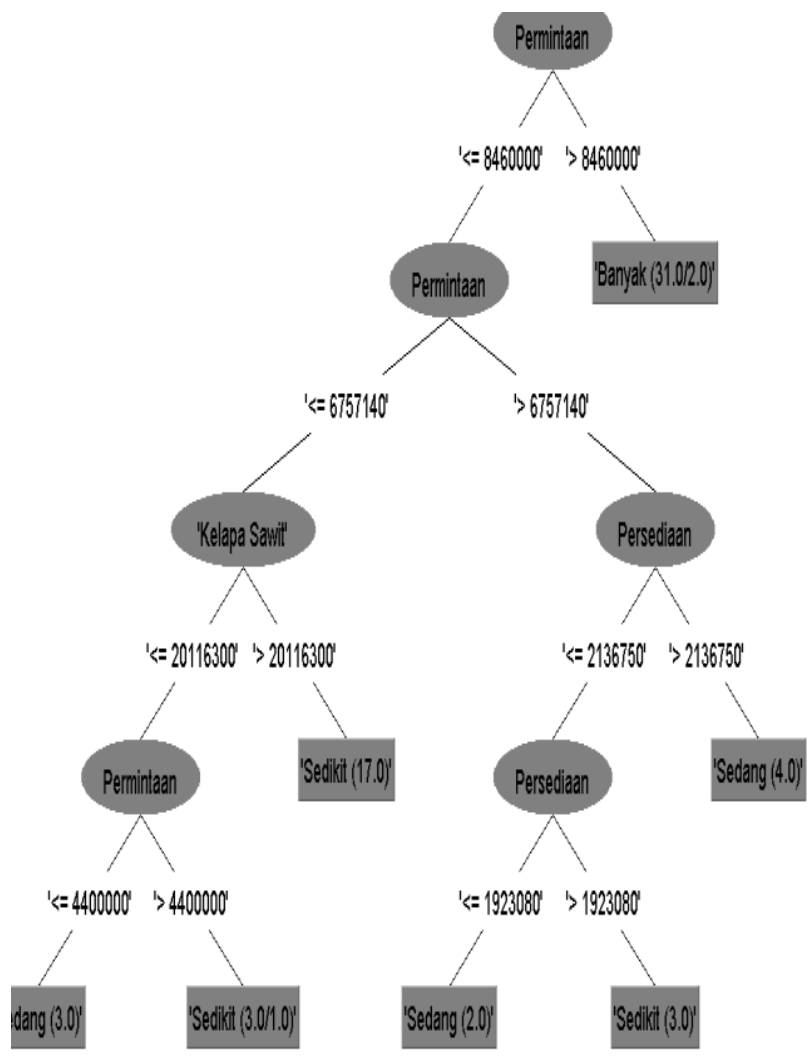

Gambar 2. Testing Pembentukan Pohon Keputusan J48

Berdasarkan Gambar 2. Testing Pembentukan Pohon Keputusan J48, maka dapat diperoleh batas nilai yang terbentuk dari aturan WEKA batasan datanya adalah sebagai berikut:

\begin{tabular}{ccc} 
& \multicolumn{2}{c}{ Tabel 3. Batasan Nilai Kriteria } \\
\hline Kriteria & $\begin{array}{c}\text { Himpunan } \\
\text { Fuzzy }\end{array}$ & \multicolumn{1}{c}{ Nilai Batasan } \\
& Sedikit & $\leq 4.400 .000$ \\
Permintaan & Sedang & $4.401 .000-8.460 .00$ \\
& Banyak & Lebih dari 8.460 .00 \\
Kelapa & Sedikit & $\leq 20.116 .300$ \\
sawit (KG) & Banyak & Lebih dari 20.116 .300 \\
& Sedikit & $\leq 1.923 .080$ \\
Persediaan & Sedang & $1.923 .081-2.136 .750$ \\
(Liter) & Banyak & Lebih dari 2.136.750
\end{tabular}

Berdasarkan Gambar 2. Testing Pembentukan Pohon Keputusan J48 dan Tabel 3. Batasan Nilai Kriteria, maka rule yang terbentuk dari testing J48 adalah sebagai beriku: 
Tabel 4. Rule Testing J48

\begin{tabular}{ll}
\hline Rule & Kondisi \\
\hline R1 & $\begin{array}{l}\text { IF Permintaan Sedang AND Kelapa sawit Sedikit } \\
\text { AND Permintaan Sedikit THEN Produksi Sedang }\end{array}$ \\
R2 & $\begin{array}{l}\text { IF Permintaan Sedang AND Kelapa sawit Sedikit } \\
\text { THEN Produksi Sedikit }\end{array}$ \\
R3 & $\begin{array}{l}\text { IF Permintaan Sedang AND Kelapa sawit Banyak } \\
\text { THEN Produksi Sedikit }\end{array}$ \\
R4 & $\begin{array}{l}\text { IF Permintaan Sedang AND Persediaan Sedang } \\
\text { AND Persediaan Sedang THEN Produksi Sedang }\end{array}$ \\
& \\
R5 & IF Permintaan Sedang AND Persediaan Sedang \\
& THEN Produksi Sedikit \\
R6 & IF Permintaan Sedang AND Persediaan Banyak \\
R7 & THEN Produksi Sedang \\
& IF Permintaan Banyak THEN Produksi Banyak \\
\hline
\end{tabular}

Terdapat tujuh rule yang terbentuk berdasarkan Tabel 4. Rule Testing J48 akan tetapi dalam satu rule terdapat kriteria yang terulang kembali, yaitu R1 dan R4 maka rule tersebut tidak layak untuk digunakan, maka perlu ditransformasikan kembali menjadi seperti berikut ini:

b. Mengubah Semua Parameter Input dan Output Menjadi Himpunan Fuzzy

Testing pembentukan pohon keputusan J48 tidak layak, maka semua parameter kriteria input dan output dirubah menjadi himpunan fuzzy, untuk menghindari kriteria terulang kembali dalam satu rule, maka Tabel 2. Perubahan Kriteria Output Produksi berubah menjadi seperti berikut:

\begin{tabular}{|c|c|c|c|}
\hline $\begin{array}{c}\text { Kelapa } \\
\text { Sawit } \\
(\mathrm{Kg})\end{array}$ & $\begin{array}{l}\text { Permintaan } \\
\text { (Liter) }\end{array}$ & $\begin{array}{l}\text { Persediaan } \\
\text { (Liter) }\end{array}$ & $\begin{array}{c}\text { Produksi } \\
\text { (Liter) }\end{array}$ \\
\hline Banyak & Sedikit & Banyak & Sedikit \\
\hline Banyak & Banyak & Banyak & Banyak \\
\hline Banyak & Banyak & Banyak & Banyak \\
\hline Banyak & Sedikit & Sedikit & Sedikit \\
\hline Banyak & Sedang & Banyak & Sedang \\
\hline Banyak & Banyak & Sedikit & Banyak \\
\hline Banyak & Banyak & Banyak & Banyak \\
\hline Banyak & Sedikit & Banyak & Sedikit \\
\hline Banyak & Banyak & Sedikit & Banyak \\
\hline Banyak & Banyak & Banyak & Banyak \\
\hline Banyak & Banyak & Sedikit & Banyak \\
\hline Banyak & Sedang & Banyak & Sedang \\
\hline Banyak & Sedang & Sedang & Sedikit \\
\hline Banyak & Banyak & Sedikit & Banyak \\
\hline Banyak & Banyak & Banyak & Banyak \\
\hline Banyak & Banyak & Banyak & Banyak \\
\hline Banyak & Banyak & Banyak & Banyak \\
\hline Banyak & Sedikit & Sedikit & Sedikit \\
\hline Sedikit & Sedikit & Sedang & Sedang \\
\hline Banyak & Sedikit & Banyak & Sedikit \\
\hline & --------- & --------- & --------- \\
\hline- & ---------- & --------- & -------- \\
\hline Banyak & Banyak & Sedikit & Banyak \\
\hline
\end{tabular}

Setelah itu testing kembali dengan WEKA untuk membentuk pohon keputusan J48, REPTree, dan Random Treee dengan cara seperti berikut:

a. $\mathrm{J} 48$

Cara membentuk suatu pohon keputusan dengan menggunakan decision tree J48 yang terdapat di tools WEKA adalah simpan Tabel 5. Perubahan Semua Kriteria Input dengan format (*.csv), selanjutnya panggil data tersebut ke WEKA, setelah itu pilih tree yang dimaksud, maka akan muncul hasil seperti berikut:

\begin{tabular}{ll}
\multicolumn{2}{c}{ Tabel 6. Informasi Akurasi J48 } \\
\hline Informasi & Akurasi \\
\hline Correctly Classified & $95,2381 \%$ \\
Incorrectly Classified & $4,7619 \%$ \\
Kappa Statistic & 0,9234 \\
Mean Absolute Error & 0,0572 \\
Root Mean Squared Error & 0,1691 \\
Relative Absolute Error & $13,703 \%$ \\
Root Relative Squared Error & $37,0719 \%$ \\
\hline
\end{tabular}

\begin{tabular}{|c|c|c|c|}
\hline \multirow[t]{2}{*}{ Informasi } & \multicolumn{3}{|c|}{ Class } \\
\hline & Sedikit & Sedang & Banyak \\
\hline TP Rate & 0,913 & 0,909 & 1 \\
\hline FP Rate & 0 & 0,019 & 0,059 \\
\hline Precision & 1 & 0,909 & 0,935 \\
\hline Recall & 0,913 & 0,909 & 1 \\
\hline F-Measure & 0,955 & 0,909 & 0,967 \\
\hline ROC Area & 0,977 & 0,969 & 0,971 \\
\hline \multicolumn{4}{|c|}{ Tabel 8. Confusion Matrix J48 } \\
\hline $\mathrm{a}$ & 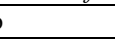 & $\mathrm{c}$ & Classified \\
\hline 21 & & 1 & $\mathrm{a}=$ Sedikit \\
\hline 0 & 9 & 0 & $\mathrm{~b}=$ Banyak \\
\hline 0 & & 10 & $\mathrm{c}=$ Sedang \\
\hline
\end{tabular}

Berikutnya yaitu menampilkan pohon keputusan dengan cara klik kanan pada result list, kemudian pilih visualize tree, maka akan muncul pohon keputusan J48 seperti berikut:

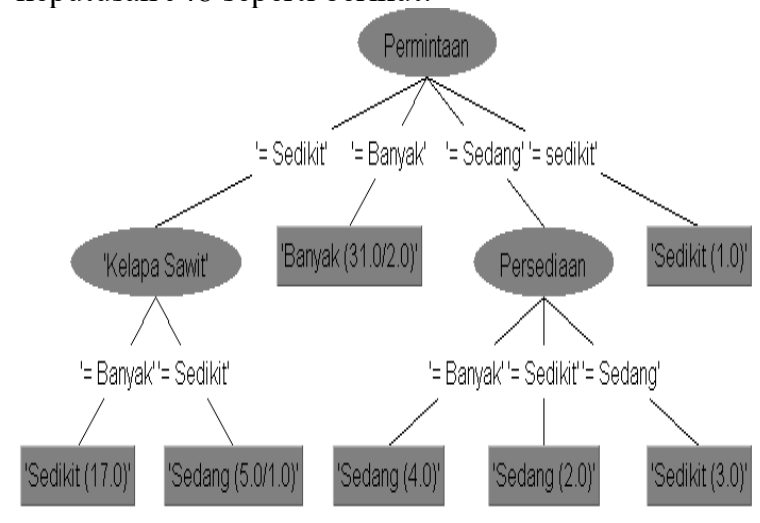

Gambar 3. Pembentukan Pohon Keputusan J48

Berdasarkan Gambar 3. Pembentukan Pohon Keputusan J48, maka rule yang terbentuk sebanyak 7 rule, seperti terlihat pada Tabel 9. Rule J48 berikut ini:

\begin{tabular}{ll}
\multicolumn{2}{c}{ Tabel 9. Rule J48 } \\
\hline Rule & Kondisi \\
\hline R1 & IF Permintaan Sedikit AND Kelapa sawit Banyak \\
& THEN Produksi Sedikit \\
R2 & $\begin{array}{l}\text { IF Permintaan Sedikit AND Kelapa sawit Sedikit } \\
\text { THEN Produksi Sedang }\end{array}$ \\
R3 & IF Permintaan Banyak THEN Produksi Banyak \\
\hline
\end{tabular}




\begin{tabular}{|c|c|}
\hline Rule & Kondisi \\
\hline R4 & $\begin{array}{l}\text { IF Permintaan Sedang AND Persediaan Banyak } \\
\text { THEN Produksi Sedang }\end{array}$ \\
\hline R5 & $\begin{array}{l}\text { IF Permintaan Sedang AND Persediaan Sedikit } \\
\text { THEN Produksi Sedang }\end{array}$ \\
\hline R6 & $\begin{array}{l}\text { IF Permintaan Sedang AND Persediaan Sedang } \\
\text { THEN Produksi Sedikit }\end{array}$ \\
\hline R7 & IF Permintaan Sedikit THEN Produksi Sedikit \\
\hline
\end{tabular}

b. REPTree

Hasil yang didapatkan oleh decision tree REPTree adalah sebagai berikut:

\begin{tabular}{ll}
\multicolumn{2}{c}{ Tabel 10. Informasi Akurasi REPTree } \\
\hline Informasi & Akurasi \\
\hline Correctly Classified & $90,4762 \%$ \\
Incorrectly Classified & $9,5238 \%$ \\
Kappa Statistic & 0,8489 \\
Mean Absolute Error & 0,0995 \\
Root Mean Squared Error & 0,2231 \\
Relative Absolute Error & $23,8412 \%$ \\
Root Relative Squared Error & $48,8992 \%$ \\
\hline
\end{tabular}

Tabel 11. Detail Akurasi Kelas REPTree

\begin{tabular}{llll}
\hline \multirow{2}{*}{ Informasi } & \multicolumn{3}{c}{ Class } \\
\cline { 2 - 4 } & Sedikit & Sedang & Banyak \\
\hline TP Rate & 0,783 & 0,909 & 1 \\
FP Rate & 0 & 0,077 & 0,059 \\
Precision & 1 & 0,714 & 0,935 \\
Recall & 0,783 & 0,909 & 1 \\
F-Measure & 0,878 & 0,8 & 0,967 \\
ROC Area & 0,954 & 0,937 & 0,971 \\
\hline
\end{tabular}

\begin{tabular}{llll}
\multicolumn{5}{c}{ Tabel 12. Confusion Matrix REPTree } \\
\hline $\mathrm{a}$ & $\mathrm{b}$ & $\mathrm{c}$ & Classified \\
\hline 18 & 1 & 4 & $\mathrm{a}=$ Sedikit \\
0 & 29 & 0 & $\mathrm{~b}=$ Banyak \\
0 & 1 & 10 & $\mathrm{c}=$ Sedang \\
\hline
\end{tabular}

Berikutnya yaitu menampilkan pohon keputusan dengan cara klik kanan pada result list, kemudian pilih visualize tree, maka akan muncul pohon keputusan REPTree seperti berikut:

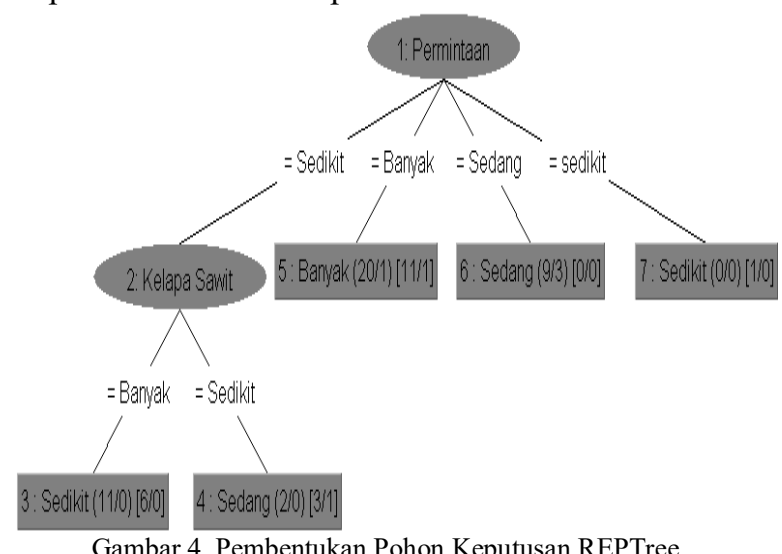

Gambar 4. Pembentukan Pohon Keputusan REPTree

Berdasarkan Gambar 4. Pembentukan Pohon Keputusan REPTree, maka rule yang terbentuk sebanyak 5 rule, seperti terlihat pada Tabel 8. Rule REPTree berikut ini:
Tabel 13. Rule REPTree

\begin{tabular}{ll}
\hline Rule & Kondisi \\
\hline R1 & IF Permintaan Sedikit AND Kelapa sawit Banyak \\
& THEN Produksi Sedikit \\
R2 & IF Permintaan Sedikit AND Kelapa sawit Sedikit \\
& THEN Produksi Sedang \\
R3 & IF Permintaan Banyak THEN Produksi Banyak \\
R4 & IF Permintaan Sedang THEN Produksi Sedang \\
& \\
R5 & IF Permintaan Sedikit THEN Produksi Sedikit \\
\hline
\end{tabular}

c. Random Tree

Hasil yang didapatkan oleh decision tree Random Tree adalah sebagai berikut:

\begin{tabular}{ll}
\multicolumn{2}{c}{ Tabel 14. Informasi Akurasi Random Tree } \\
\hline Informasi & Akurasi \\
\hline Correctly Classified & $95,2381 \%$ \\
Incorrectly Classified & $4,7619 \%$ \\
Kappa Statistic & 0,9234 \\
Mean Absolute Error & 0,0536 \\
Root Mean Squared Error & 0,1636 \\
Relative Absolute Error & $12,8264 \%$ \\
Root Relative Squared Error & $35,8666 \%$ \\
\hline
\end{tabular}

Tabel 15. Detail Akurasi Kelas Random Tree

\begin{tabular}{llll}
\multirow{2}{*}{ Informasi } & \multicolumn{3}{c}{ Class } \\
\cline { 2 - 4 } & Sedikit & Sedang & Banyak \\
\hline TP Rate & 0,913 & 0,909 & 1 \\
FP Rate & 0 & 0,019 & 0,059 \\
Precision & 1 & 0,909 & 0,935 \\
Recall & 0,913 & 0,909 & 1 \\
F-Measure & 0,955 & 0,909 & 0,967 \\
ROC Area & 0,985 & 0,978 & 0,98 \\
\hline
\end{tabular}

\begin{tabular}{llll}
\multicolumn{5}{c}{ Tabel 16. Confusion Matrix Random Tree } \\
\hline $\mathrm{a}$ & $\mathrm{b}$ & $\mathrm{c}$ & Classified \\
\hline 21 & 1 & 1 & $\mathrm{a}=$ Sedikit \\
0 & 29 & 0 & $\mathrm{~b}=$ Banyak \\
0 & 1 & 10 & $\mathrm{c}=$ Sedang \\
\hline Berikut & hasil pohon & keputusan & Random Tree
\end{tabular}
yang terbentuk:

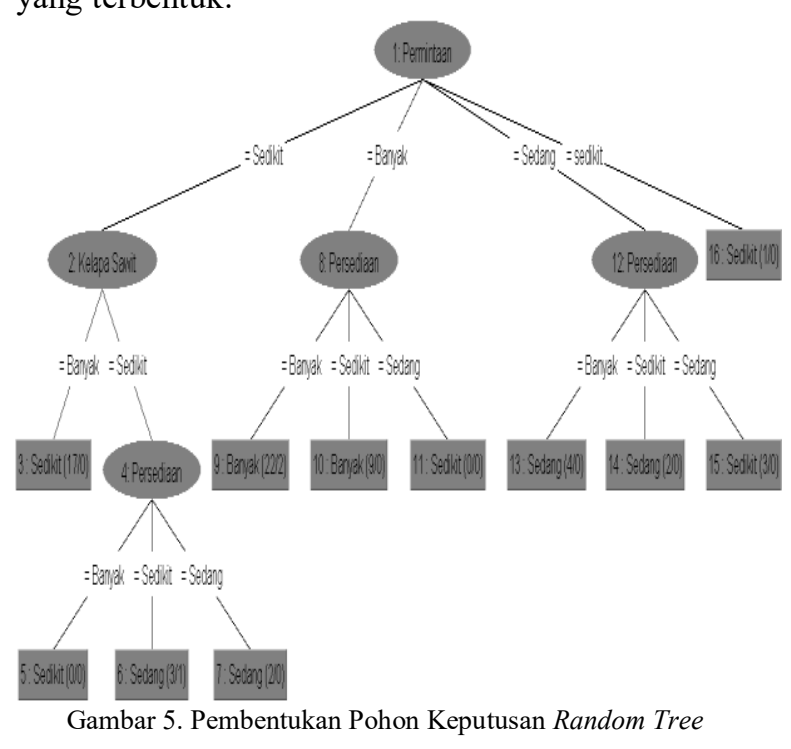

Berdasarkan Gambar 5. Pembentukan Pohon Keputusan Random Tree, maka rule yang terbentuk 
sebanyak 11 rule, seperti terlihat pada Tabel 17. Rule Random Tree berikut ini:

Tabel 17. Rule Random Tree

\begin{tabular}{ll}
\hline Rule & Kondisi \\
\hline R1 & IF Permintaan Sedikit AND Kelapa sawit Banyak \\
& THEN Produksi Sedikit \\
R2 & IF Permintaan Sedikit AND Kelapa sawit Sedikit \\
& AND Persediaan Banyak THEN Produksi Sedikit \\
R3 & IF Permintaan Sedikit AND Kelapa sawit Sedikit \\
& AND Persediaan Sedikit THEN Produksi Sedang \\
R4 & IF Permintaan Sedikit AND Kelapa sawit Sedikit \\
& AND Persediaan Sedang THEN Produksi Sedang \\
& \\
R5 & IF Permintaan Banyak AND Persediaan Banyak \\
& THEN Produksi Banyak \\
R6 & IF Permintaan Banyak AND Persediaan Sedikit \\
& THEN Produksi Banyak \\
R7 & IF Permintaan Banyak AND Persediaan Sedang \\
& THEN Produksi Sedikit \\
R8 & IF Permintaan Sedang AND Persediaan Banyak \\
& THEN Produksi Sedang \\
R9 & IF Permintaan Sedang AND Persediaan Sedikit \\
R10 & THEN Produksi Sedang \\
IF Permintaan Sedang AND Persediaan Sedang \\
R11 & THEN Produksi Sedikit \\
& IF Permintaan Sedikit THEN Produksi Sedikit \\
&
\end{tabular}

6) Fuzzy Tsukamoto

Berikut contoh penyelesaian prediksi produksi minyak kelapa sawit menggunakan metode fuzzy Tsukamoto dengan menggunakan rule J48, REPTree, dan Random Tree:

Perusahaan Tapian Nadenggan adalah suatu perusahaan pembuat minyak kelapa sawit, dari Tabel 1. Dataset, data diambil dari bulan Januari tahun 2014 sampai dengan bulan Maret tahun 2019 yang diketahui perbulannya, banyaknya kelapa sawit maksimum 43.500.000 kilogram, banyaknya kelapa sawit minimum 16.572.300 kilogram, permintaan maksimum 18920000 liter, permintaan minimum 3.153.333 liter, persediaan maksimum 5.000.000 liter dan persediaan minimum 833.333 liter, serta produksi maksimum 19.800.000 liter, dan produksi minimum 6.000.000 liter. Diketahui banyaknya kelapa sawit saat ini pada bulan April tahun 2019 sebesar 25.184.500 kilogram dan permintaan saat ini sebesar 14.231.000 liter, persediaan saat ini sebesar 2.821.000 liter. Berapa jumlah produksi yang harus diproduksi Perusahaan Tapian Nadenggan pada bulan April 2019?

\section{Penyelesaian:}

Penyelesaian metode fuzzy Tsukamoto dengan menggunakan decision tree REPTree:

\section{Langkah 1:}

Pembuatan rule dengan menggunakan konsep decision tree REPTree yang nampak pada Tabel 8.

\section{Langkah 2:}

Membuat pemodelan fuzzy untuk setiap kritera dengan menggunakan kurva linier naik, turun, dan segitiga. Pada kasus ini, ada 4 variabel yang akan dimodelkan, yaitu:

a. Kelapa sawit (a), terdiri atas 3 himpunan fuzzy, yaitu SEDIKIT, SEDANG, dan BANYAK .Berdasarkan dari data yang diperoleh, maka model fungsi keanggotaan kelapa sawit digambarkan sebagai berikut:

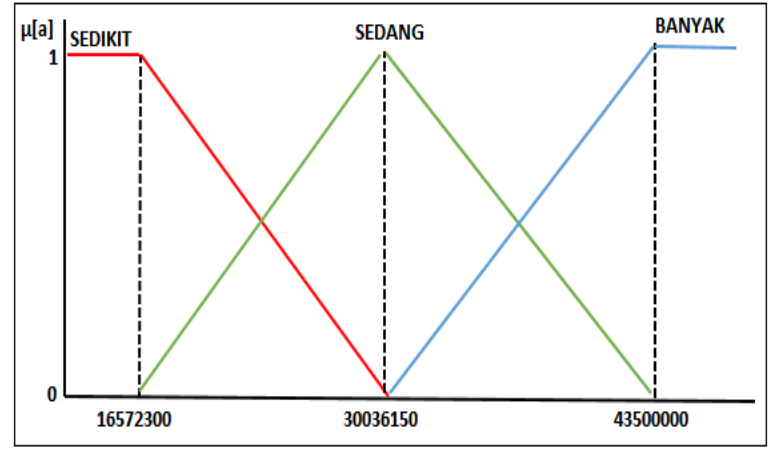

Gambar 6. Kurva Kelapa Sawit (Bulan)

$\mu$ kelapasawit sedikit[a]:

$$
\left\{\begin{array}{cl}
0 & \mathrm{a} \geq 30.036 .150 \\
\frac{30.036 .150-\mathrm{a}}{30.036 .150-16.572 .300}, & 16.572 .300 \leq \mathrm{a} \leq 30.036 .150 \\
1 & \mathrm{a} \leq 16.572 .300
\end{array}\right.
$$

$\mu$ kelapasawit_sedang[a]:

$$
\begin{aligned}
& \left\{\begin{array}{cl}
0 & \mathrm{a} \leq 16.572 .300 \text { atau } \mathrm{a} \geq 43.500 .000 \\
\frac{\mathrm{a}-16.572 .300}{30.036 .150-16.572 .300}, & 16.572 .300 \leq \mathrm{a}<30.036 .150 \\
\frac{43.500 .000-\mathrm{a}}{43.500 .000-30.036 .150}, & 30.036 .150<\mathrm{a} \leq 43.500 .000 \\
1 & \mathrm{a}=30.036 .150
\end{array}\right. \\
& \left\{\begin{array}{cl}
0 & \mathrm{a} \leq 30.036 .150 \\
\frac{\mathrm{a}-30.036 .150}{43.500 .000-30.036 .150} & , \quad 30.036 .150 \leq \mathrm{a} \leq 43.500 .000 \\
1 & \mathrm{a} \geq 43.500 .000
\end{array}\right.
\end{aligned}
$$

Jika diketahui banyaknya kelapa sawit sebanyak 25.184.500 kilogram, maka:

$$
\begin{aligned}
\boldsymbol{\mu}_{\text {kelapasawit-sedikit [25184500] }} & =\frac{30.036 .150-25.184 .500}{13.463 .850} \\
& =0,36034641 \\
\boldsymbol{\mu}_{\text {kelapasawit-sedang[ 25184500] }} & =\frac{25.184 .500-16.572 .300}{13.463 .850} \\
& =0,63965359 \\
\boldsymbol{\mu}_{\text {kelapasawit-banyak[25184500] }} & =0
\end{aligned}
$$

b. Permintaan (b), terdiri atas 3 himpunan fuzzy, yaitu SEDIKIT, SEDANG, dan BANYAK .Berdasarkan dari data yang diperoleh, maka model fungsi keanggotaan permintaan 
dirumuskan sebagai berikut :

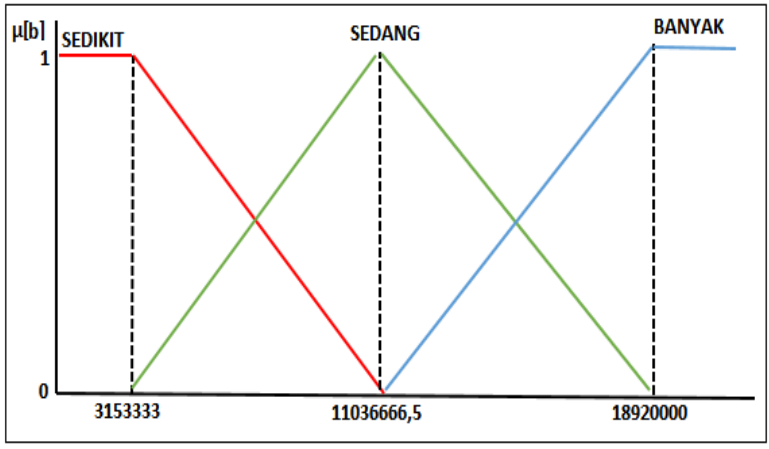

Gambar 7. Kurva Permintaan (Bulan)

ppermintaan_sedikit[b]:

$\left\{\begin{array}{cc}0 & b \geq 1.1036 .666 .5 \\ \frac{11.036 .666 .5-b}{11.036 .666 .5-3.153 .333} & , \quad 3.153 .333 \leq b \leq 11.036 .666 .5 \\ 1 & b \leq 3.153 .333\end{array}\right.$

$\mu$ permintaan_sedang[b]:

$\left\{\begin{array}{cl}0 & b \leq 3.153 .333 \text { atau } b \geq 18.920 .000 \\ \frac{b-3.153 .333}{11.036 .666 .5-3.153 .333}, & 3.153 .333 \leq b<11.036 .666 .5 \\ \frac{18.920 .000-b}{18.920 .000-11.036 .666 .5}, & 11.036 .666 .5<b \leq 18.920 .000 \\ 1 & b=11.036 .666 .5\end{array}\right.$

upermintaan_banyak[b]:

$\left\{\begin{array}{cl}0 & b \leq 11.036 .666 .5 \\ \frac{b-11.036 .666 .5}{18.920 .000-11.036 .666 .5}, & 11.036 .666 .5 \leq b \leq 18.920 .000 \\ 1 & b \geq 18.920 .000\end{array}\right.$

Jika diketahui banyaknya permintaan sebanyak 14.231.000 liter, maka:

$$
\begin{aligned}
\boldsymbol{\mu}_{\text {permintaan-sedikit }[14231000]} & =0 \\
\boldsymbol{\mu}_{\text {permintaan-sedang }[14231000]} & =\frac{18.920 .000-14.231 .000}{7.883 .333 .5} \\
& =0,59479914
\end{aligned}
$$$$
\boldsymbol{\mu}_{\text {permintaan-banyak[14231000 ] }}=\frac{14.231 .000-11.036 .666 .5}{7.883 .333,5}
$$$$
=0.40520086
$$

c. Persediaan (c), terdiri atas 3 himpunan fuzzy, yaitu SEDIKIT, SEDANG dan BANYAK .Berdasarkan dari data yang diperoleh, maka fungsi keanggotaan persediaan dirumuskan sebagai berikut :

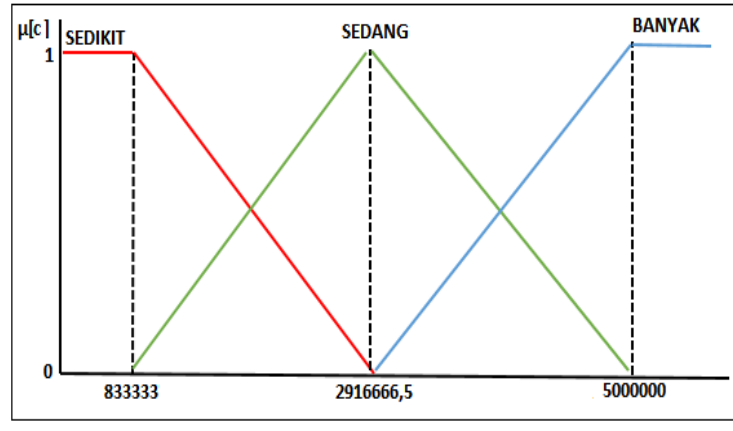

Gambar 8. Kurva Persediaan (Bulan)

ppersediaan_sedikit[c]:

$$
\left\{\begin{array}{cl}
0 & \mathrm{c} \geq 2.916 .666 .5 \\
\frac{2.916 .666 .5-\mathrm{c}}{2.916 .666 .5-833.333}, & 833.333 \leq \mathrm{c} \leq 2.916 .666 .5 \\
1 & \mathrm{c} \leq 833.333
\end{array}\right.
$$

upersediaan_sedang[c]:

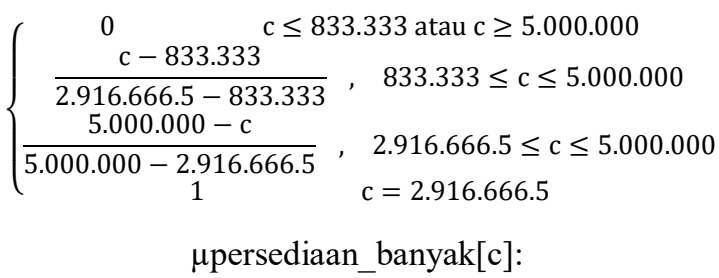

$$
\left\{\begin{array}{cc}
0 & c \leq 2.916 .666 .5 \\
\frac{c-2.916 .666 .5}{5.000 .000-2.916 .666 .5}, & 2916666.5 \leq \mathrm{c} \leq 5.000 .000 \\
1 & \mathrm{c} \geq 5.000 .000
\end{array}\right.
$$

Jika diketahui banyaknya persediaan sebanyak 2.821.000 liter, maka:

$$
\begin{aligned}
\boldsymbol{\mu}_{\text {persediaan-sedikit [2821000] }} & =\frac{2.916 .666 .5-2.821 .000}{2.083 .333 .5} \\
& =0.04591992 \\
\boldsymbol{\mu}_{\text {persediaan-sedang [2821000 ] }} & =\frac{2.821 .000-833.333}{2.083 .333 .5} \\
& =0.95408008 \\
\boldsymbol{\mu}_{\text {persediaann-banyak [2821000] }} & =0
\end{aligned}
$$

d. Jumlah produksi (z), terdiri atas 3 himpunan fuzzy, yaitu SEDIKIT, SEDANG, dan BANYAK .Berdasarkan dari data yang diperoleh, maka fungsi keanggotaan jumlah produksi dirumuskan sebagai berikut : 


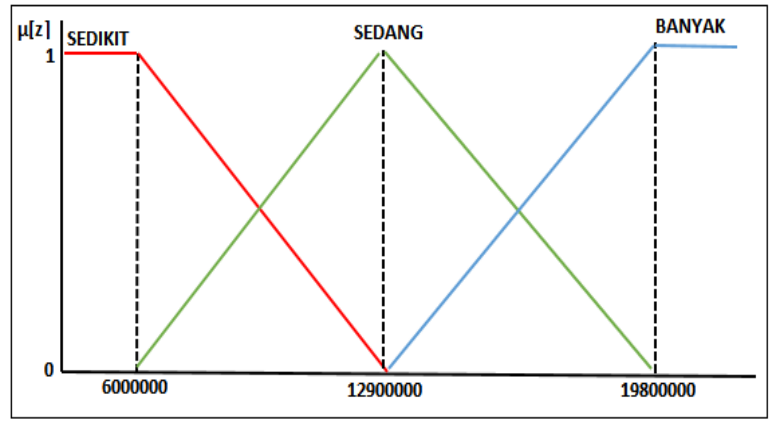

Gambar 9. Kurva Produksi (Bulan)

$\mu$ produksi_sedikit[z]:

$$
\left\{\begin{array}{cc}
0 & \mathrm{z} \geq 12.900 .000 \\
\frac{12.900 .000-\mathrm{z}}{12.900 .000-6.000 .000} & , \quad 6.000 .000 \leq \mathrm{z} \leq 12.900 .000 \\
1 & \mathrm{z} \leq 6.000 .000
\end{array}\right.
$$

$\mu$ produksi_sedang[z]:

$$
\begin{gathered}
\left\{\begin{array}{cc}
0 & \mathrm{z} \leq 6.000 .000 \text { atau } \mathrm{z} \geq 19.800 .000 \\
\frac{\mathrm{z}-6.000 .000}{12.900 .000-6.000 .000}, & 6.000 .000 \leq \mathrm{z} \leq 12.900 .000 \\
\frac{19.800 .000-\mathrm{z}}{19.800 .000-12.900 .000}, & 12.900 .000 \leq \mathrm{z} \leq 19.800 .000
\end{array}\right. \\
\text { Mproduksi_banyak[z]: } \\
\left\{\begin{array}{cc}
\mathrm{z}=12.900 .000 \\
\frac{\mathrm{z}-12.900 .000}{19.800 .000-12.900 .000}, & \mathrm{z} \leq 12.900 .000 \\
1 & \mathrm{z} \geq 19.800 .000
\end{array}\right.
\end{gathered}
$$

\section{Langkah 3:}

Aplikasi fungsi implikasi menggunakan fungsi MIN, dapat mencari nilai $\mathrm{z}$ pada setiap aturan untuk aturan yang terbentuk menggunakan decision tree REPTree:

\section{R1: IF Permintaan Sedikit AND Kelapa sawit Banyak} THEN Produksi Sedikit

$$
\begin{aligned}
& \alpha_{-} 1=\min (0 ; 0) \\
& =0 \\
& \frac{12.900 .000-z}{12.900 .000-6.000 .000}=0 \\
& Z_{1}=12.900 .000
\end{aligned}
$$

R2: IF Permintaan Sedikit AND Kelapa sawit Sedikit THEN Produksi Sedang

$$
\begin{aligned}
& \begin{array}{l}
\alpha 2=\min (0 ; 0,36034641) \\
=0
\end{array} \\
& \frac{\mathrm{z}-6.000 .000}{12.900 .000-6.000 .000}=0 \\
& Z_{2}=6.000 .000 \\
& \frac{19.800 .000-\mathrm{z}}{19.800 .000-12.900 .000}=0
\end{aligned}
$$

$$
Z_{3}=19.800 .000
$$

R3: IF Permintaan Banyak THEN Produksi Banyak

$$
\begin{aligned}
& \alpha_{-} 3=0,405200 \\
& \frac{\mathrm{z}-12.900 .000}{19.800 .000-12.900 .000}=0,405200 \\
& \mathrm{Z}_{4}=15.695 .885,9218
\end{aligned}
$$

R4: IF Permintaan Sedang THEN Produksi Sedang

$$
\begin{gathered}
\alpha_{-} 4=0,59479914 \\
\frac{\mathrm{z}-6.000 .000}{12.900 .000-6.000 .000}=0,59479914 \\
Z_{5}=10.104 .114,078 \\
\frac{19.800 .000-\mathrm{z}}{19.800 .000-12.900 .000}=0,59479914 \\
Z_{6}=15.695 .885,922
\end{gathered}
$$

R5: IF Permintaan Sedikit THEN Produksi Sedikit $\alpha \_5=0$

$$
\begin{gathered}
\frac{12.900 .000-\mathrm{z}}{12.900 .000-6.000 .000}=0 \\
\mathrm{Z}_{5}=12.900 .000
\end{gathered}
$$

Langkah 4:

Hasil atau output diperoleh dengan menggunakan defuzzification rata-rata terbobot yaitu:

$$
\begin{aligned}
Z & =\frac{\Sigma(\alpha * z)}{\Sigma \alpha} \\
Z & =\frac{21.705 .804,3038}{1} \\
& \approx 21.705 .804
\end{aligned}
$$

Jadi jumlah produksi minyak kelapa sawit yang harus diproduksi oleh Perusahaan PT Tapian Nadenggan adalah sebanyak 21.705.804 liter.

Berikutnya penyelesaian metode fuzzy Tsukamoto dengan menggunakan decision tree J48 dan Random Tree: Langkah yang dilakukan sama seperti metode fuzzy Tsukamoto dengan menggunakan decision tree REPTree yang membuat berbeda adalah base rule yang terbentuk, dimana base rule yang terbentuk untuk decision tree J48 nampak pada Tabel 7. Rule J48, dan base rule yang terbentuk untuk Random Tree nampak pada Tabel 9. Rule Random Tree sehingga jumlah produksi minyak kelapa sawit yang harus diproduksi oleh Perusahaan PT Tapiana Nadenggan dengan menggunakan J48 adalah sebanyak 11.360.182 liter, sedangkan 
menggunakan Random Tree sebanyak 10.182.474 liter.

8) Uji Data dan Perbandingan Akurasi

Uji hasil perbandingan akurasi prediksi produksi minyak kelapa sawit menggunakan metode error Average Forecasting Error Rate (AFER). Adapun perhitungannya adalah:

$$
\mathrm{AFER}=\frac{\sum\left(\frac{\left|A_{\mathrm{i}}-F_{\mathrm{i}}\right|}{A_{\mathrm{i}}}\right)}{n} \times 100 \%
$$

Dimana $A i$ adalah nilai aktual pada data dan $F i$ adalah nilai hasil peramalan untuk data ke-i. Adapun $\mathrm{n}$ adalah banyaknya data. (Jilani, Burney, dan Ardil, 2007).

\begin{tabular}{|c|c|c|c|c|c|}
\hline Bulan & Tahun & $\begin{array}{l}\text { Produksi } \\
\text { Riil (A) }\end{array}$ & $\begin{array}{l}\text { Prediksi } \\
\text { (F) }\end{array}$ & $|A-F|$ & $|\mathrm{A}-\mathrm{F}| / \mathrm{A}$ \\
\hline April & 2019 & 16.972 .000 & 11.360 .182 & 5.611 .818 & 0,3307 \\
\hline Mei & 2019 & 16.170 .000 & 10.554 .476 & 5.615 .524 & 0,3473 \\
\hline Juni & 2019 & 22.350 .000 & 24.527 .073 & 2.177 .073 & 0,0974 \\
\hline Juli & 2019 & 19.275 .000 & 11.505 .458 & 7.769 .542 & 0,4031 \\
\hline Agustus & 2019 & 18.432 .800 & 14.013 .160 & 4.419 .640 & 0,2398 \\
\hline Septem & 2019 & 18.876 .000 & 17.374 .430 & 1.501 .570 & 0,0795 \\
\hline \multicolumn{5}{|c|}{ Rata-rata } & 0,2496 \\
\hline \multicolumn{5}{|c|}{ Dalam persen } & $24,96 \%$ \\
\hline
\end{tabular}

Tabel 19. Data Uji Hasil Prediksi Produksi REPTree

\begin{tabular}{|c|c|c|c|c|c|}
\hline Bulan & Tahun & $\begin{array}{l}\text { Produksi } \\
\text { Riil (A) }\end{array}$ & $\begin{array}{l}\text { Prediksi } \\
\text { (F) }\end{array}$ & $|A-F|$ & $|\mathrm{A}-\mathrm{F}| / \mathrm{A}$ \\
\hline April & 2019 & 16.972 .000 & 21.705 .804 & 4.733 .804 & 0,2789 \\
\hline Mei & 2019 & 16.170 .000 & 21.940 .577 & 5.770 .577 & 0,3569 \\
\hline Juni & 2019 & 22.350 .000 & 21.658 .814 & 691.186 & 0,0309 \\
\hline Juli & 2019 & 19.275 .000 & 22.081 .504 & 2.806 .504 & 0,1456 \\
\hline Agustus & 2019 & 18.432 .800 & 23.030 .871 & 4.598 .071 & 0,2495 \\
\hline Septem & 2019 & 18.876 .000 & 25.075 .480 & 6.199 .480 & 0,3284 \\
\hline \multicolumn{5}{|c|}{ Rata-rata } & 0,2317 \\
\hline \multicolumn{5}{|c|}{ Dalam persen } & $23,17 \%$ \\
\hline
\end{tabular}

Tabel 20. Data Uji Hasil Prediksi Produksi Random Tree

\begin{tabular}{ccllll}
\hline Bulan & Tahun & $\begin{array}{l}\text { Produksi } \\
\text { Riil }(\mathrm{A})\end{array}$ & $\begin{array}{l}\text { Prediksi } \\
(\mathrm{F})\end{array}$ & $|\mathrm{A}-\mathrm{F}|$ & $|\mathrm{A}-\mathrm{F}| / \mathrm{A}$ \\
\hline April & 2019 & 16.972 .000 & 10.182 .474 & 6.789 .526 & 0,4000 \\
Mei & 2019 & 16.170 .000 & 12.137 .653 & 4.032 .347 & 0,2494 \\
Juni & 2019 & 22.350 .000 & 15.660 .740 & 6.689 .260 & 0,2993 \\
Juli & 2019 & 19.275 .000 & 9.507 .803 & 9.767 .197 & 0,5067 \\
Agustus & 2019 & 18.432 .800 & 11.114 .050 & 7.318 .750 & 0,3971 \\
Septem & 2019 & 18.876 .000 & 12.496 .309 & 6.379 .691 & 0,3379 \\
& \multicolumn{5}{c}{ Rata-rata } \\
& \multicolumn{6}{c}{ Dalam persen } & & 0,3651 \\
& \multicolumn{6}{c}{} & $36,51 \%$ \\
\hline
\end{tabular}

Berdasarkan perhitungan tersebut didapatkan nilai AFER dengan metode Tsukamoto menggunakan rule Tree J48 sebesar 24,96\%, menggunakan rule REPTree sebesar 23,17\%, dan menggunakan rule Random Tree sebesar 36,51\%, yang berarti bahwa metode Tsukamoto menggunakan rule REPTree mempunyai nilai error yang lebih kecil dan mempunyai tingkat akurasi yang lebih tinggi dibandingkan dengan rule Tree J48 dan Random Tree.

\section{KESIMPULAN}

Berdasarkan hasil penelitian mengenai fuzzy Tsukamoto dengan menggunakan decision tree $\mathrm{J} 48$ REPTree, dan Random Tree dapat diambil kesimpulan bahwa model basis aturan dalam penelitian ini berupa pohon keputusan yang dapat digunakan untuk Fuzzy dengan keakuratan 95,2381\% untuk decision tree J48, 90,4762\% untuk decision tree REPTree, dan 95,2318\% untuk decision tree Random Tree. Hasil analisis perbandingan secara langsung dengan data yang sesungguhnya bahwa decision tree yang paling mendekati data sesungguhnya dengan menggunakan metode fuzzy Tsukamoto adalah decision tree REPTree dikarenakan berdasarkan data uji pada bulan April, Mei, Juni, Juli, Agustus, dan September tahun 2019 mengatakan bahwa hasil metode decision tree REPTree mempunyai tingkat error yang lebih kecil sebesar 23,17\% dibandingkan dengan J48 sebesar 24,96\% dan Random Tree sebesar 36,51\% pada prediksi jumlah produksi minyak kelapa sawit. Oleh karena itu, ditemukan sebuah gagasan bahwa akurasi pohon keputusan yang terbentuk menggunakan tools WEKA tidak menjamin akurasi yang terbesar adalah yang terbaik, buktinya dari kasus ini REPTree memiliki akurasi rule paling kecil, akan tetapi hasil prediksi memiliki tingkat error paling kecil, dibandingkan dengan J48 dan Random Tree.

\section{DAFTAR PUSTAKA}

HARSITI, MUNANDAR, T. A. and SIGIT, H. T. (2013) 'Implementation Of Fuzzy-C4.5 Classification As a Decision Support For Students Choice Of Major Specialization', International Journal Engineering Research \& Technology (IJERT), 2(11), pp. 1577-1581. Available at: http://worldwidescience.org/wws/desktop/en/ ostiblue/service/link/track?redirectUrl.

HIDAYATI, J. et al. (2013) 'Optimization of Business Partners Feasibility for Oil Palm Revitalization Using Fuzzy Approach', 3(2), pp. 29-35.

JULIANSYAH, A. (2015) 'Penerapan Metode Fuzzy Tsukamoto Untuk Memprediksi Hasil Produksi Kelapa Sawit ( Studi Kasus ':, Pelita Informatika Budi Darma, 9(3), pp. 130-137.

KUSUMADEWI, 2010. Aplikasi Logika Fuzzy Untuk Pendukung Keputusan, Graha Ilmu Yogyakarta

MUJAHID, T. A. and SELA, E. I. (2019) 'Analisis Perbandingan Rule Pakar dan Decision Tree J48 Dalam Menentukan Jumlah Produksi Kain Tenun Menggunakan Metode Fuzzy Tsukamoto', 6(5), pp. 501-505. 
SELYWITA, D. and HAMDANI (2013) 'Sistem Pendukung Keputusan Pemilihan Supplier Obat Menggunakan Metode Fuzzy Tsukamoto', 3(1), pp. 21-30.

SUKANDY, D. M., BASUKI, A. T. and PUSPASARI, S. (2014) 'Penerapan Metode Fuzzy Mamdani Untuk Memprediksi Jumlah Produksi Minyak Sawit Berdasarkan Data Persediaan Dan Jumlah Permintaan ( Studi Kasus Pt Perkebunan Mitra Ogan Baturaja )', Program Studi Teknik Informatika, pp. 1-9. doi: 10.1080/13607863.2011.629092.

SOLIKIN, F. (2013) 'Aplikasi Logika Fuzzy Dalam Optimisasi Produksi Barang Menggunakan Metode Mamdani Dan Metode Sugeno', 2013(Sentika).

T. A. JILANI, S. M. A. BURNEY, C. ARDIL, 2007. Fuzzy Metric Approach for Fuzzy Time Series Forecasting based on Frequency Density Based Partitioning, Proceedings of World Academy of Science, Engineering and technology, vol. 23, pp.333-338.

TSENG, T. L. (BILL), KONADA, U. and KWON, Y. (JAMES) (2016) 'A novel approach to predict surface roughness in machining operations using fuzzy set theory', Journal of Computational Design and Engineering. Elsevier, 3(1), pp. 1-13. doi: 10.1016/j.jcde.2015.04.002.

TUNDO, AKBAR, R. and SELA, E. I. (2020) 'Analisis Perbandingan Fuzzy Tsukamoto Dan Sugeno Dalam Menentukan Jumlah Produksi Kain Tenun Menggunakan Base Rule Decision Tree', Jurnal Teknologi Informasi dan Ilmu Komputer (JTIIK), 7(1), pp. 171-180. doi: 10.25126/jtiik.202071751.

TUNDO and SELA, E. I. (2018) 'APPLICATION OF THE FUZZY INFERENCE SYSTEM METHOD TO PREDICT', (IJID) International Journal on Informatics for Development, 7(1), pp. 1-9. 
Halaman ini sengaja dikosongkan 